\title{
THE REMOVAL OF DISPERSE DYE FROM WATER BY ADSORPTION ON A NEW ADSORBENT
}

\author{
Aleksandra Mičić1 ${ }^{*}$, Olivera Stanković1 ${ }^{\text {, Ivanka Ristić2 }}{ }^{\text {, Dragan } Đ o r đ e v i c ́ 1 ~}$
}

(ORIGINAL SCIENTIFIC PAPER)

UDC 677.2:541.183:661.18

${ }^{1}$ Faculty of Technology, Leskovac, Serbia

${ }^{2}$ Higher Technological and Artistic Professional School Leskovac, Serbia

The investigation represents the study of the possibility of using a new adsorbent, i.e. a natural waste material (short cotton fibers from weaving mill), after physical and chemical modification, in the processes of removing disperse dye molecules from water. The aim of the study is to use the obtained results in practice, i.e. to find out a new system for discoloration of the liquid effluent from dyeing of synthetic textiles. The obtained adsorbent is in the form of a relatively finely dispersed material with heterogeneous porous particles, below $100 \mu \mathrm{m}$. The adsorbent infrared spectrum shows specific peaks corresponding to functional groups typical for this type of material. Disperse dye is adsorbed faster at the beginning, and slower later until the equilibrium concentration is established. After the transformation of cotton waste fibers, the yield of the new adsorbent is $45 \%$. The amount of adsorbed dispersed dye per weight unit of adsorbent is increased with the adsorption process duration.
Keywords: cotton fibers, weaving mill, adsorbent, disperse dye.

\section{Introduction}

The intensive development of the textile industry is accompanied by the increasing quantity of wastewater, which in terms of environmental protection and sustainable development requires the need to improve the existing and introduce new wastewater treatment processes [1,2].

Special scientific and technological attention requires textile dyes, some of which are very difficult to degrade in nature. Certain dyes are susceptible to bioaccumulation and due to harmful properties they often threat human health and the environment. The application of physicochemical methods for removing textile dyes from wastewater is often restricted by high costs, the need for disposal of the resulting harmful sludge or the formation of toxic degradation components [3,4].

An adsorbent of natural origin adsorbs a large number of organic and inorganic substances from the water, removes the unpleasant smell and taste, and reduces turbidity and hardness of water. It also binds microorganisms and products of their activity, as well as residues resulting from their decomposition by other techniques. Such adsorption capacity of adsorbents is explained by highly developed porosity and a chemical reactivity of its surface $[5,6]$.

The study includes two researching areas. The first one is relating to the functional modification of waste cotton and the production of a natural adsorbent, while the other one concerns the adsorption of a disperse textile dye which could be a potential waste after dyeing of synthetic textile.

Therefore, a significant amount of the solid waste from the weaving mill should be reduced and used to produce a usable product-adsorbent, as well as to remove textile disperse dye from the water.

\section{Experimental}

The used material

Short waste cotton fibers from the textile industry were used for the adsorbent preparation. Cotton waste samples were collected in the weaving mill. One gripper loom during operation in one shift produces the waste cotton fibers in the amount of $170-200 \mathrm{~g}$.

Waste water models were prepared using disperse dye C.I. Disperse Red $\left.167 \mathrm{M}\left(\mathrm{C}_{22} \mathrm{H}_{24} \mathrm{ClN}_{5} \mathrm{O}_{7}\right)=505.9 \mathrm{~g} \cdot \mathrm{mol}^{-1}\right)$ and the structure is shown in Fig. 1.

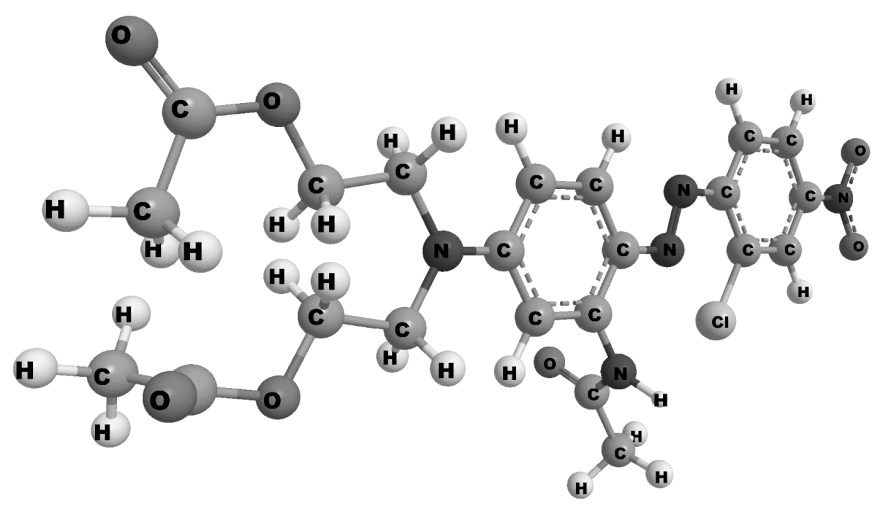

Figure 1. The structure of Disperse Red 167 dye [6]

\footnotetext{
*Author address: Aleksandra Mičić, Faculty of Technology, University of Nis, Bulevar oslobodjenja 124, 16000 Leskovac, Serbia,

E-mail: micic.aleksandra86@gmail.com

The manuscript received: April, 03, 2019.

Paper accepted: May, 11, 2019.
} 
The process of obtaining the adsorbent

Collected waste cotton fibers were washed with detergent $\left(4 \mathrm{~g} \cdot \mathrm{dm}^{-3}\right)$ in warm distilled water $\left(60{ }^{\circ} \mathrm{C}\right.$, bath ratio $1: 100)$, dried and treated with concentrated phosphoric acid (85\%, Tehnohemija Serbia), for $48 \mathrm{~h}$ at room temperature $\left(18-20{ }^{\circ} \mathrm{C}\right.$, ratio: $1 \mathrm{~g}$ of waste : $5 \mathrm{~g}$ of acid). After the treatment and squeezing, the sample was dried at $100{ }^{\circ} \mathrm{C}$ for $3 \mathrm{~h}$. Further, the sample was packed in an aluminum foil and burned in the oven at $450{ }^{\circ} \mathrm{C}$ for $2 \mathrm{~h}$. After cooling in the air, the sample was rinsed with distilled water and neutralized (sodium carbonate, Tehnohemija, Serbia). Finally, the sample was dried $\left(100^{\circ} \mathrm{C}\right)$ and ground, and used in the experimental adsorption of disperse dye from the water solution.

\section{Adsorption procedure}

The adsorbent was suspended in the solution of disperse dye (adsorbate) in reaction vessels. Adsorption took place using a stirrer with the rotation movement $\left(130 \mathrm{~min}^{-1}\right)$ at $20^{\circ} \mathrm{C}$ for a specified time. The quantity of adsorbent was $1 \mathrm{~g}$ constantly, while the solution of the constant quantity of $100 \mathrm{~cm}^{3}$ contained disperse dye of various concentrations: $20,40,60,80$ and $100 \mathrm{mg} \cdot \mathrm{dm}^{-3}$. The processing time with constant stirring was $3,6,10$ 20 and $30 \mathrm{~min}$. All experiments were performed at $\mathrm{pH} 3$ of the solution.

The above dye concentrations were used because they mainly correspond to residual quantities of the same type of the dye in the solution, after commercial dyeing of synthetic textile material. The equilibrium adsorption time was $30 \mathrm{~min}$.

Upon the completion of the adsorption process, the aliquot of the dye solution was used to measure the absorption on the spectrophotometer. The unknown quantities of the dye in the solution after adsorption were determined by using calibration curves .

\section{Measuring methods}

- Mass loss of the cotton waste after washing with detergent was calculated according to equation (1):

Mass loss, $\%=\frac{\text { Mass before washing }- \text { Mass after washing }}{\text { Mass before washing }} \times 100 \ldots \ldots$

- Yield of adsorbent was calculated by using equation (2):

Yield, $\%=\frac{\text { Mass of adsorbent obtained }}{\text { Mass of cotton waste fibers }} \times 100$

- Ultraviolet-visible spectrophotometer (Cary 100 Conc UV-VIS, Varian) was used to measure the absorbance. The spectrum of the disperse dye solution shows a max peak at $600 \mathrm{~nm}$, so the absorbance is measured at the wavelength.

- Scanning electron microscopy (SEM) JEOL JSM 6610LV applying acceleration voltage of $20 \mathrm{kV}$, was used for analyzing of the adsorbent surface morphology.

- Fourier-transform infrared spectroscopy BOMEM Hartmann \& Braun MB Series in the range of wave num- bers $4000-400 \mathrm{~cm}^{-1}$ was used. Potassium bromide tablet technique was used to get infrared spectrum.

- Efficiency of the dye removal or an exhaustion degree was calculated according to equation (3) [7]:

Removed dye, $\%=\frac{C_{0}-C}{C_{0}} \times 100$

where: $C_{0}$ and $C$ are the initial and final concentration of the dye solution, respectively.

- The amount adsorbed of the dye per mass unit of adsorbent after time $t$ was calculated by using equation (4) [7]:

$q_{t}=\frac{\left(C_{0}-C_{t}\right) \cdot v}{w}$

where: $C_{0}$ is the initial adsorbent concentration $\left(\mathrm{mg} \cdot \mathrm{dm}^{-3}\right)$, $C_{t}$ is the sorbent concentration after adsorption time $t$ $\left(\mathrm{mg} \cdot \mathrm{dm}^{-3}\right), w$ is the mass of adsorbent $(\mathrm{g})$ and $V$ is the volume of the adsorption solution $\left(\mathrm{dm}^{3}\right)$.

\section{Results and discussion}

Basically, a concrete research is a study of the possibility of using the natural waste material (short cotton fibers from the weaving mill), after physico-chemical modification, in the processes of the adsorption-removal of dye molecules from water.

The mass loss after washing the raw cotton waste amounts to about $11 \%$. The yield after transformation of cotton waste fibers into the adsorbent, according to the applied procedure, is about $45 \%$.

\section{Characterization of adsorbent}

The surface morphology of the obtained adsorbent, with a magnification of $250 x$, is shown with a micrograph (Figure 2). The used adsorbent is a relatively fine bulk material with heterogeneous porous particles, of various shapes and forms, generally smaller than $100 \mu \mathrm{m}$. Depths of larger particles contain pronounced cracks, cavities and channels that form the basis of the microporous material. Similar visual porosity is typical in other adsorbents and is recognized by the presence of particles of a very irregular shape, a high degree of amorphization, and a large number of voids in the interior. Pores are different in the shape and accessibility to the adsorbent molecules, which is associated with the fact that they can be closed, open at one or both ends, and isolated or interconnected.

It is assumed that dye molecules penetrate relatively easily into the interior of the particles through the pores and channels, where they are adsorbed into a number of internal active centers. The porous structure of the surface facilitates dye diffusion into the interior of the pores, as it was observed in other studies [8]. 


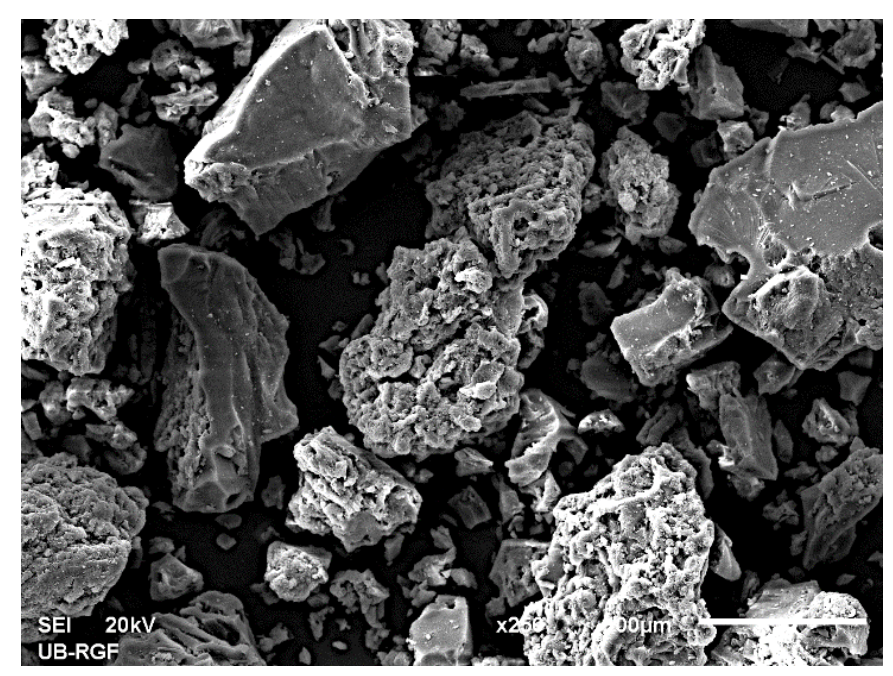

Figure 2. SEM micrograph of the applied adsorbent
Figure 3 shows the FTIR spectrum of the used adsorbent. The broadband at $3442 \mathrm{~cm}^{-1}$ corresponded to stretching $v(\mathrm{O}-\mathrm{H})$ vibration of hydroxyl groups. The two strong characteristic peaks at $2922 \mathrm{~cm}^{-1}$ and $2852 \mathrm{~cm}^{-1}$ corresponded to the aromatic showed the FTIR spectrum of the used adsorbent. The broadband at $3442 \mathrm{~cm}^{-1}$ corresponded to stretching $v(\mathrm{C}-\mathrm{H})$ vibration of the alkene group. The peak at $1703 \mathrm{~cm}^{-1}$ showed the carbonyl stretching $v(\mathrm{C}=\mathrm{O})$ vibration, whereas the peaks at 1618 $\mathrm{cm}^{-1}$ and $1457 \mathrm{~cm}^{-1}$ showed the alkene (variable band) and aromatic stretching $v(\mathrm{C}=\mathrm{C})$ vibrations, respectively. Similarly, $\mathrm{C}-\mathrm{H}$ group of the benzene ring and aromatic alcohol were allocated at $728 \mathrm{~cm}^{-1}$ and $617 \mathrm{~cm}^{-1}$, whereas $552 \mathrm{~cm}^{-1}$ represented the outer of plane bending of $\mathrm{C}-\mathrm{O}$ bonds of alcohols [8,9].

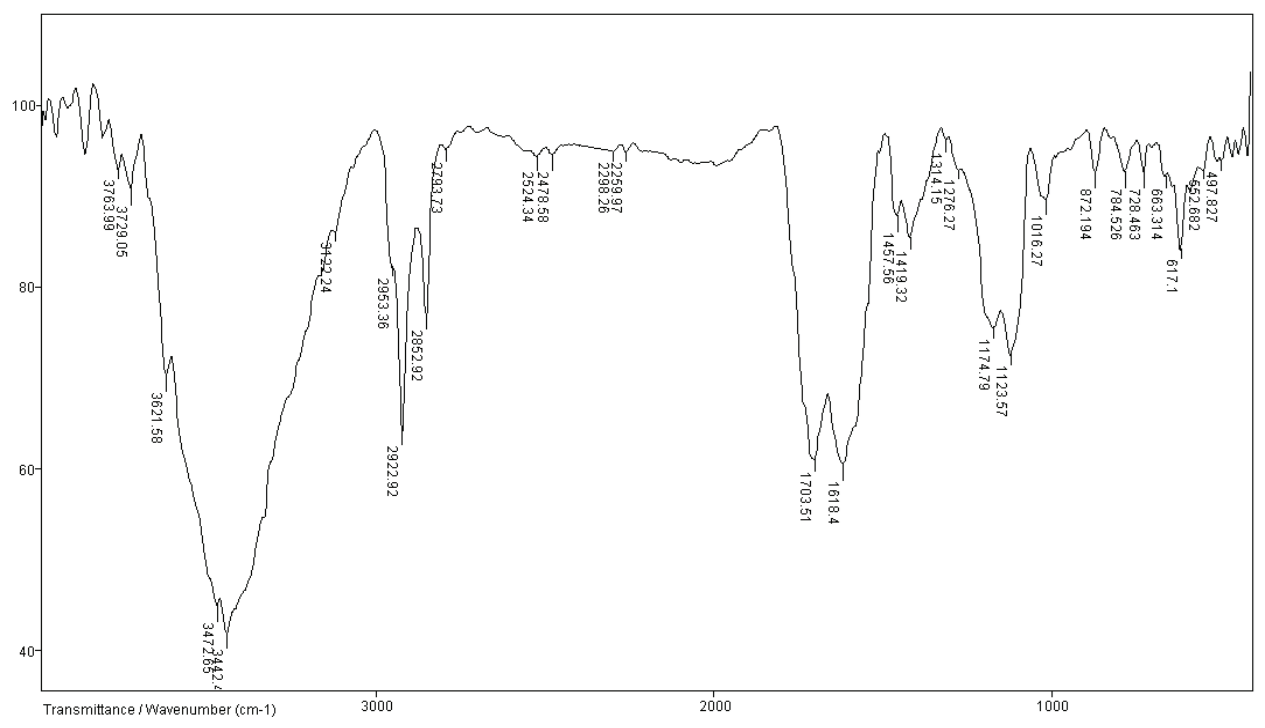

Figure 3. FTIR spectrum of the applied adsorbent

Adsorption of disperse dye on the adsorbent-effect of various parameters

The nature of decolorization is closely related to the acid-base properties of the applied adsorbent surface. It is known that the surface of the adsorbent obtains a positive charge from the adsorbable hydrogen ion $\left(\mathrm{H}^{+}\right)$ after immersing in water. With low $\mathrm{pH}$ and the increase of $\mathrm{H}^{+}$ions concentration, the adsorbent surface intensively receives a positive charge. In the particular case, the maximum adsorption occurs at $\mathrm{pH}$ 2-3 for disperse dye solutions, which is a highly acidic environment (Figure 4 ). The disperse dye ionizes in the acidic environment in aqueous solutions. The higher absorption of the dye to the adsorbent, which is obtained at a very acidic $\mathrm{pH}$, could be attributed to electrostatic interactions between the positively charged adsorbent and the negatively charged anion of the disperse dye [10].

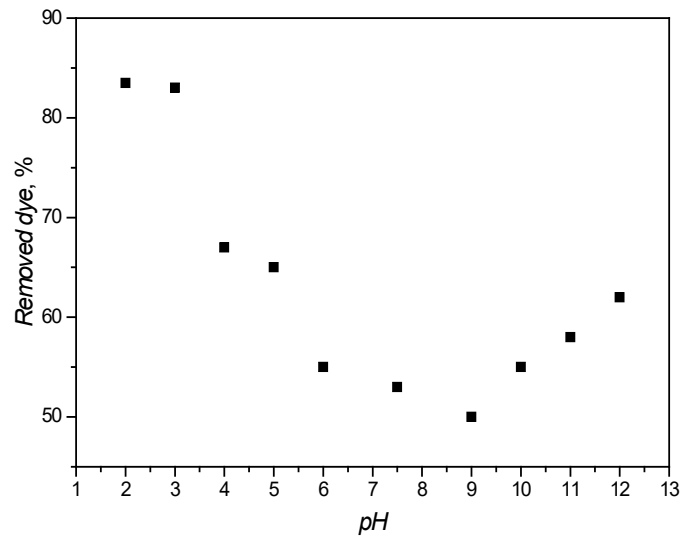

Figure 4. The effect of $\mathrm{pH}$ on the adsorption of disperse dye $\left(20^{\circ} \mathrm{C}, 1 \mathrm{~g}\right.$ adsorbent, dye $\left.20 \mathrm{mg} \cdot \mathrm{dm}^{-3}\right)$ 
The effect of the contact time on the removal of the disperse dye by the adsorbent is graphically depicted in Figure 5. It is noticeable that with the duration of the dyeing process, the dye concentration in the solution is reduced, which is expected and slightly intense with higher initial dye concentrations. This can be explained by the fact that at the beginning the dye ions are adsorbed by the outer surface of the adsorbent. When the adsorption of the outer surface reaches saturation, the dye ions will also be adsorbed into the interior of the particles [10].

The adsorption efficiency depends on several parameters: temperature, $\mathrm{pH}$, mechanical mixing, dye diffusion speed, etc. The selected disperse dye has poor solubility, which reduces its substantivity for the aqueous phase since the dye may show a greater tendency towards the fiber or some other adsorbent [10].

If changes in the amount of the dye for the same time are observed for the initial concentration of $20 \mathrm{mg} \cdot \mathrm{dm}^{-3}$ after $10 \mathrm{~min}$, the dye concentration in the solution was $7.8 \mathrm{mg} \cdot \mathrm{dm}^{-3}$ for the initial concentration of $60 \mathrm{mg} \cdot \mathrm{dm}^{-3}$, that is $30.6 \mathrm{mg} \cdot \mathrm{dm}^{-3}$ while for the maximum initial concentration it was $60.9 \mathrm{mg} \cdot \mathrm{dm}^{-3}$.

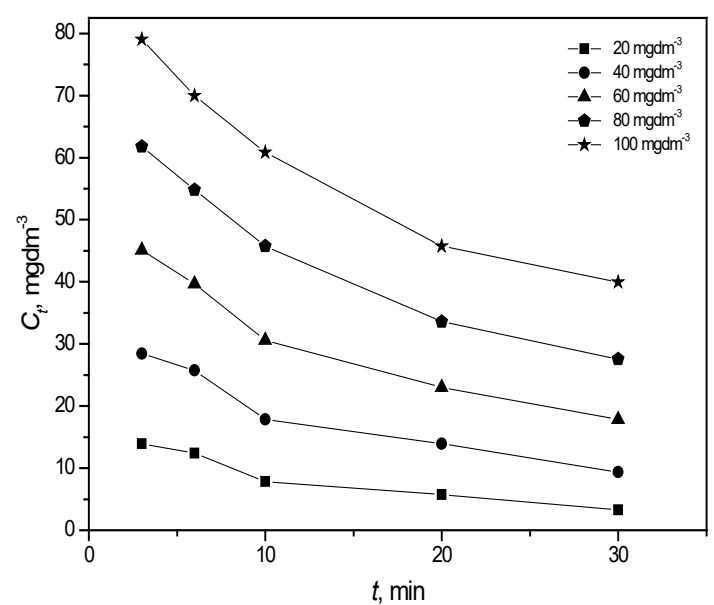

Figure 5. The change of the disperse dye amount in the solution during adsorption

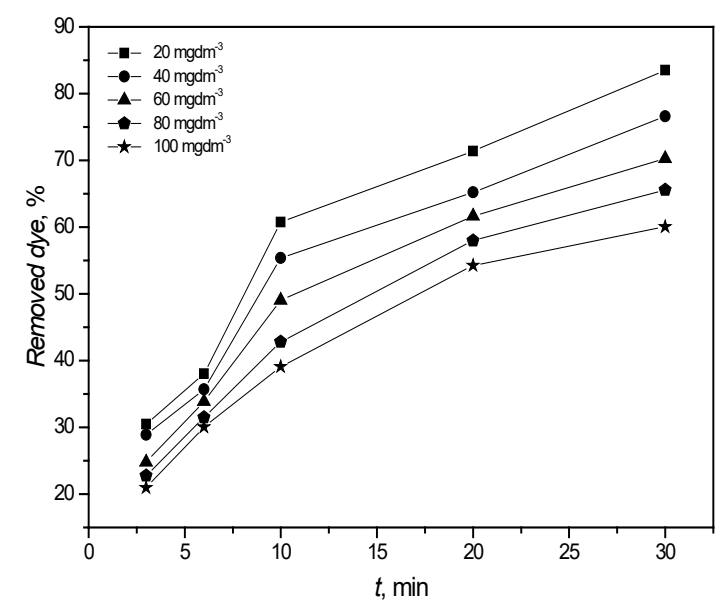

Figure 6. Removed disperse dye during adsorption
According to the diagram (Figure 6), it is noticeable that the amount of removed dye after adsorption increases with time, which is expected to be slightly higher at lower initial concentrations of the disperse dye. In all initial dye concentrations, a slightly intense change was observed in the first 10 min of adsorption, while in the subsequent adsorption period, this change was less pronounced.

Figure 7 shows a change in the adsorbed amount of the dye per unit mass of the adsorbent over time, for different initial dye concentrations. The diagram in this Figure shows that the amount of the adsorbed dye per unit mass of the adsorbent increases with the duration of the adsorption process.

In a more detailed analysis of the changes, it was observed that at the concentration of $20 \mathrm{mg} \cdot \mathrm{dm}^{-3}, q_{t}$ is $1.67 \mathrm{mg} \cdot \mathrm{g}^{-1}$, at $60 \mathrm{mg} \cdot \mathrm{dm}^{-3} q_{t}$ is $4.21 \mathrm{mg} \cdot \mathrm{g}^{-1}$, and at the end, at $100 \mathrm{mg}^{-\mathrm{dm}^{-3}}, q_{t}$ is $6.00 \mathrm{mg}$ of the dye per $1 \mathrm{~g}$ of the adsorbent.

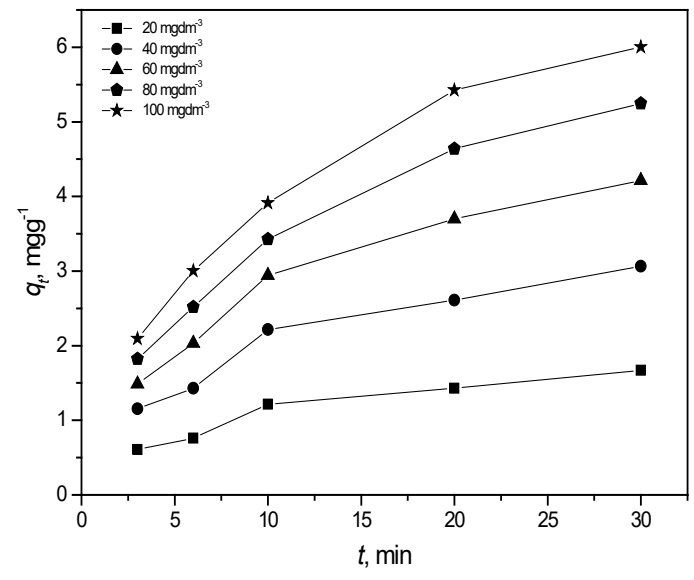

Figure 7. Amount adsorbed of disperse dye on adsorbent

The effect of the initial concentration of the dye on its exhaustion or the quantity of the removed dye is checked in the concentration range of $20-100 \mathrm{mg} \cdot \mathrm{dm}^{-3}$ (Fig. 8). By increasing the initial dye concentration, the dye exhaustion is reduced although the actual amount of the dye adsorbed per unit mass of the adsorbent has increased with the increase of the initial concentration. The initial concentration of the dye in the solution gives it an important driving force to overcome the mass transfer resistance between the aqueous and solid phase. The initial color concentration does not affect the time required to reach the equilibrium, but rather determines the speed of the dye mass transfer through the solution onto the surface of the adsorbents with the same mass, as the stirring speed is constant.

According to the curves in the diagram, the dye exhaustion is highest at smaller initial concentrations. The calculation showed the opposite. The exhaustion is actually the highest at the highest initial concentrations.

For example, according to the results in Figure 8, after adsorption on the adsorbent: 
- at the dye concentration of $20 \mathrm{mg} \cdot \mathrm{dm}^{-3}$ for $30 \mathrm{~min}$ the exhaustion is $83.5 \%$ of the dye,

- at the dye concentration of $100 \mathrm{mg} \cdot \mathrm{dm}^{-3}$ for $30 \mathrm{~min}$ the exhaustion is $60.0 \%$ of the dye,

i.e.

- $20 \mathrm{mg} \cdot \mathrm{dm}^{-3} \times 83.5 \% / 100=16.7 \mathrm{mg} \cdot \mathrm{dm}^{-3}$ (exhausted after $30 \mathrm{~min}$ of dyeing)

- $100 \mathrm{mg} \cdot \mathrm{dm}^{-3} \times 60.0 \% / 100=60.0 \mathrm{mg} \cdot \mathrm{dm}^{-3}$ (exhausted after 30 min of dyeing)

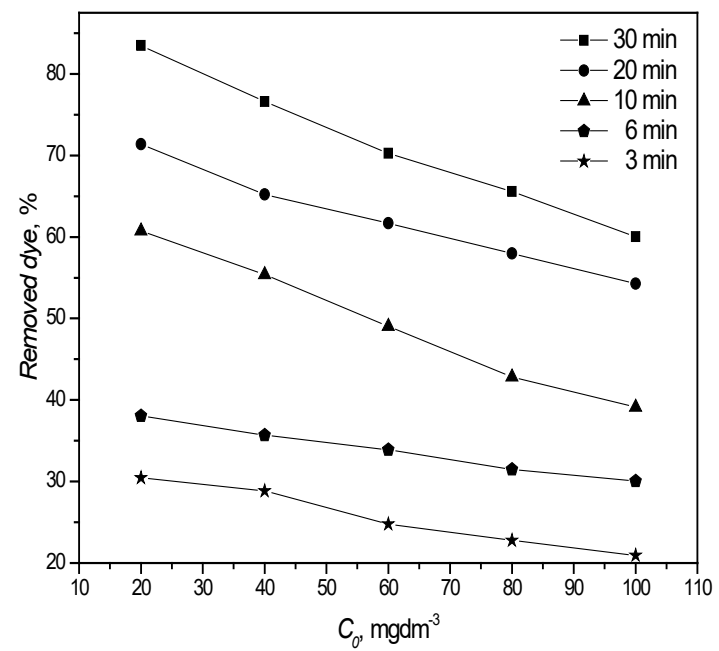

Figure 8. Removed disperse dye depending on the initial dye concentration during adsorption

\section{Conclusion}

For the adsorption of molecules of the disperse dye from the water solution, the adsorbent obtained from waste fibers was used. The resulting product can serve as a productive, simple and inexpensive way to, for example, decolorization of the effluent from the textile industry. A couple of interesting data came to light in the adsorption study. The mass loss after washing of the raw cotton waste amounts to $11 \%$. After modification or transformation of cotton waste fibers into the adsorbent, the yield is $45 \%$. The adsorbent is a relatively fine bulk material with heterogeneous porous particles of various shapes and forms, generally less than $100 \mu \mathrm{m}$ in size. The infrared spectrum of the adsorbent has characteristic peaks corresponding to functional groups typical of such adsorbents.

Large differences in the dye adsorption, in the function of the solution $\mathrm{pH}$ show that this parameter is of more importance for the adsorption of the applied dye. The disperse dye is more quickly adsorbed at the beginning and then slower, to achieve the equilibrium concentration after $30 \mathrm{~min}$, after which there are no significant changes in the residual dye concentration in the solution. The amount of the adsorbed dye per unit mass of the adsorbent increases with the duration of the adsorption process. By increasing the initial dye concentration, the dye exhaustion is reduced in all cases, although the actual amount of the dye adsorbed per unit mass of the adsorbent increases with the increase of the initial concentration.

\section{References}

[1] H-G. Han, Z. Liu, Y-N. Guo, J.-F. Qiao, An intelligent detection method for bulking sludge of wastewater treatment process, Journal of Process Control, 68 (2018) $118-128$

[2] P. Gikas, Towards energy positive wastewater treatment plants, Journal of Environmental Management, 203(2) (2017) 621 - 629.

[3] C. R. Holkar, A. J. Jadhav, D. V. Pinjari, N. M. Mahamuni, Aniruddha B. Pandit, A critical review on textile wastewater treatments: Possible approaches, Journal of Environmental Management, 182, (2016) 351 - 366.

[4] H. Hayat, Q. Mahmood, A. Pervez, Z. A. Bhatti, S. A. Baig, Comparative decolorization of dyes in textile wastewater using biological and chemical treatment, Separation and Purification Technology, 154 (2015) 149 - 153.

[5] M. J. Ahmed, Application of raw and activated Phragmites australis as potential adsorbents for wastewater treatments, Ecological Engineering, 102 (2017) 262 - 269

[6] L. Wang, Application of activated carbon derived from 'waste' bamboo culms for the adsorption of azo disperse dye: Kinetic, equilibrium and thermodynamic studies, Journal of Environmental Management, 102 (2012) 79-87.

[7] S. K. Singh, A. B. Gupta, A. K. Sharma, Fly ash as low cost adsorbent for treatment of effluent of handmade paper industry-Kinetic and modelling studies for direct black dye, Journal of Cleaner Production, 112(1) (2016) $1227-1240$.

[8] O. Kazak, Y. R. Eker, H. Bingol, A. Tor, Preparation of chemically-activated high surface area carbon from waste vinasse and its efficiency as adsorbent material, Journal of Molecular Liquids, 272 (2018) 189 - 197.

[9] S. Yorgun, D. Yıldız, Preparation and characterization of activated carbons from Paulownia wood by chemical activation with $\mathrm{H}_{3} \mathrm{PO}_{4}$, Journal of the Taiwan Institute of Chemical Engineers, 53 (2015) Pages 122 - 131.

[10] Z. Huang, Y. Li, W. Chen, J. Shi, N. Zhang, X. Wang, Z. Li, L. Gao, Y. Zhang, Modified bentonite adsorption of organic pollutants of dye wastewater, Materials Chemistry and Physicsm, 202 (2017) 266 - 276. 
Izvod

\section{UKLANJANJE DISPERZNE BOJE IZ VODE ADSORPCIJOM NA NOVI ADSORBENT}

Aleksandra Mičić1, Olivera Stanković1 ${ }^{\text {, Ivanka Ristić2 }}$, Dragan Đorđević ${ }^{1}$

(ORIGINALNI NAUČNI RAD)
UDK 677.2:541.183:661.18

${ }^{1}$ Tehnološki fakultet, Leskovac, Srbija

${ }^{2}$ Visoka tehnološko umetnička strukovna škola, Leskovac, Srbija

Konkretno istraživanje predstavlja studiju mogućnosti primene novog adsorbenta, tj. prirodnog otpadnog materijala (kratka pamučna vlakna iz pogona tkačnice), posle fizičke i hemijske modifikacije, u procesima uklanjanja molekula disperzne boje iz vode. Cilj istraživanja je upotrebiti rezultate u praksi sa tendencijom iznalaženja novog sistema za obezbojavanje tečnog otpada koji potiče od bojenja sintetičkog tekstila. Dobijeni adsorbent je relativno fino rasuti materijal sa heterogenim poroznim česticama, veličine do $100 \mu \mathrm{m}$. Infracrveni spektar adsorbenta sadrži karakteristične vibracije koje odgovaraju funkcionalnim grupama tipičnim za ovakve materijale. Disperzna boja se brže adsorbuje na početku, a onda sporije do uspostavljanja ravnotežne koncentracije. Prinos novog adsorbenta od otpadnih vlakana posle transformacije je $45 \%$. Količina adsorbovane disperzne boje, po jedinici mase adsorbenta, povećava se sa dužinom trajanja procesa adsorpcije.
Ključne reči: pamučna vlakna, tkačnica, adsorbent, disperzna boja 